\title{
The experiences of private somatology therapists on their self-management in a private practice
}

\begin{tabular}{|c|c|}
\hline \multicolumn{2}{|c|}{$\begin{array}{l}\text { Authors: } \\
\text { Karien Richter } \\
\text { Karien Jooste }^{2}\end{array}$} \\
\hline \multicolumn{2}{|c|}{$\begin{array}{l}\text { Affiliations: } \\
{ }^{1} \text { Department of Somatology, } \\
\text { University of Johannesburg, } \\
\text { South Africa }\end{array}$} \\
\hline \multicolumn{2}{|c|}{$\begin{array}{l}{ }^{2} \text { School of Nursing, } \\
\text { University of the Western } \\
\text { Cape, South Africa }\end{array}$} \\
\hline \multicolumn{2}{|c|}{$\begin{array}{l}\text { Correspondence to: } \\
\text { Karien Jooste }\end{array}$} \\
\hline \multicolumn{2}{|c|}{$\begin{array}{l}\text { Email: } \\
\text { kjooste@uwc.ac.za }\end{array}$} \\
\hline \multicolumn{2}{|c|}{$\begin{array}{l}\text { Postal address: } \\
\text { Postnet Suite \#155, Private } \\
\text { Bag X16, Hermanus 7200, } \\
\text { South Africa }\end{array}$} \\
\hline \multicolumn{2}{|c|}{$\begin{array}{l}\text { Dates: } \\
\text { Received: } 03 \text { July } 2012 \\
\text { Accepted: } 08 \text { Feb. } 2013 \\
\text { Published: } 04 \text { July } 2013\end{array}$} \\
\hline \multicolumn{2}{|c|}{$\begin{array}{l}\text { How to cite this article: } \\
\text { Richter, K. \& Jooste, K., 2013, } \\
\text { 'The experiences of private } \\
\text { somatology therapists on } \\
\text { their self-management in } \\
\text { a private practice', Health } \\
\text { SA Gesondheid 18(1), Art. } \\
\text { \#685, } 9 \text { pages. http://dx.doi. } \\
\text { org/10.4102/hsag.v18i1.685 }\end{array}$} \\
\hline \multicolumn{2}{|c|}{$\begin{array}{l}\text { Copyright: } \\
\text { C 2013. The Authors. } \\
\text { Licensee: AOSIS } \\
\text { OpenJournals. This wo } \\
\text { is licensed under the } \\
\text { Creative Commons } \\
\text { Attribution License. }\end{array}$} \\
\hline \multicolumn{2}{|l|}{ Read online: } \\
\hline 口ifos & $\begin{array}{l}\text { Scan this QR } \\
\text { code with your } \\
\text { smart phone or } \\
\text { mobile device } \\
\text { to read online. }\end{array}$ \\
\hline
\end{tabular}

Somatology therapists have a demanding occupation, both physically and emotionally. Long working hours coupled with handling clients on a daily basis, notwithstanding the strain of ensuring high quality client care, are all aspects that place pressure on the therapist. These aspects, in the backdrop of a lack of self-management of a therapist, could result in impaired judgement and substandard performance in the workplace. The purpose of this study included exploring and describing the experiences of private somatology therapists in selfmanagement, from which recommendations for improved self-management within private somatology practices were described. For the purpose of this study, self-management was defined as a method of managing not only the interaction with clients and work stressors, but also the feelings of the therapists, by practising a variety of techniques such as self-discipline. A descriptive, exploratory and contextual qualitative design was followed. The accessible population consisted of therapists $(n=15)$ practising at six private somatology facilities in the Pretoria North region. Purposeful sampling was followed. Ten individual unstructured interviews as well as a pilot study were conducted in which field notes were taken. Opencoding data analysis identified four themes with subthemes. Lincoln and Guba's model was used to ensure trustworthiness and ethical considerations were followed throughout the process. Informed consent was granted by the private somatology practices and the therapists. One of the themes indicated that self-management strategies should be displayed, in order to gain a sense of control. The study identified that there is a definite need to nurture the therapist within this demanding working environment which we call the somatology practice.

Somatologie terapeute het ' $n$ veeleisende werk hetsy fisies en emosioneel. Lang werksure, gekoppel met die hantering van kliënte op 'n daaglikse basis, asook die stremming om te alle tye ' $n$ hoë gehalte kliëntesorg te verseker, is als faktore wat spanning op die terapeut plaas. Die gebrek aan selfbestuur van 'n terapeut - in die agtergrond van die bogenoemde bydraende faktore - kan tot 'n swak oordeelsvermoë en dienooreenkomstige substandaard optrede in die werkplek lei. Die doel van hierdie studie was onder andere om die ervarings van privaat somatologie-terapeute te ondersoek en te omskryf, waarvolgens aanbevelings vir verbeterde selfbestuur in privaat somatologie-praktyke beskryf was. Vir die doeleindes van hierdie study, word selfbestuur gedefinieër as 'n metode om nie alleenik die interaksies met die kliënte en die werkstressors te bestuur nie, maar ook om die gevoelens van die terapeute te bestuur, deur middel van die uitoefening van 'n verskeidenheid tegnieke, onder andere, selfdissipline. 'n Beskrywende, ondersoekende en kontekstuele kwalitatiewe ontwerp is gevolg. Die toeganklike populasie het uit terapeute $(n=15)$ in ses private somatologie-praktyke in die Pretoria-Noordstreek bestaan. ' $n$ Doelgerigte steekproef is gevolglik geneem. Tien individuele ongestruktureerde onderhoude, asook 'n loodstudie is uitgevoer en veldnotas is geneem. Oop kodering het vier temas met subtemas geïdentifiseer. Die model van Lincolin en Guba is gebruik om betroubaarheid te verseker en etiese oorwegings is tydens die navorsingsproses gevolg. Ingeligte toestemming is deur die privaat kliniekpraktyke en deelnemers verleen. Een tema het inderdaad aangedui dat selfbestuurstrategieë gedemonstreer behoort te word om sodoende 'n gevoel van beheer te bekom. Hierdie studie het geidentifiseer dat daar 'n definitiewe behoefte is om die terapeut binne die veeleisende werksomgewing te koester wat ons die somatologiepraktyk noem.

\section{Introduction}

Somatology therapists face a demanding working environment that requires self-management. Long working hours coupled with handling clients on a daily basis, notwithstanding the strain of ensuring high quality client care, are all aspects that place pressure on the therapist. However, individuals need to ascertain how to improve their behaviour during self-management (Kreitner \& Kinicki 1998:479). Self-management is one's own behaviour when managing cognitive processes and consequences by means of planning, organising, leading and control (Jooste 2010). A somatology therapist must focus on self-control by exercising willpower, resisting temptation, 
seeking guidance, and/or by being self-disciplined (Kreitner \& Kinicki 1998:479). It is an individual specialising in therapy, trained in methods of treatment other than the use of drugs or surgery (Merriam-Webster.com 2012b). The term 'therapist' in this study refers to the somatology therapist.

Self-management entails managing one's own cognitive processes and sequences and seems to be a basic prerequisite for effective management in health care organisations. For the purpose of this study, self-management was defined as a method of managing not only the interaction with clients and work stressors, but also the feelings of the therapists, by practising a variety of techniques relating to self-discipline. This study explored the experiences of somatology therapists on self-management in the setting of a private practice. The concept 'experiences' refers to something personally encountered, undergone, or lived through (MerriamWebster.com 2012a). In this study, 'experiences' refers to the experiences of the therapist vis-à-vis their self-management in the somatology environment and explores how they experience self-management.

In a study conducted by Jacobs and Richter (2002:16), concerning the reality of working as a therapist, it became evident that most somatology therapists experience high levels of distress during normal functioning in their working environment. The industry of somatology is of such a nature that the therapist has to remain professional at all times when treating a client (Godfrey 2003:195).

Modern somatology is viewed as a highly-qualified, competitive profession, which has to adapt to a dynamic environment at a fast-moving pace. Although the industry provides for free time, it is also a site for work, involving physical labour as well as emotional work. Within this industry, long hours, low remuneration, and often poor working conditions for the employees exist (Black \& Sharma 2001a:104). Toerien and Kitzinger (2007:168) conducted research about emotional behaviour in the workplace. These authors explained how, by using conversation analysis, a single interaction between a client and a somatology therapist (the task, direct talk, and even aspects of the physical work itself) may be designed to perform a dual function, namely, to complete to satisfaction the procedure for which the client is paying, and to perform some of those actions that researchers have dubbed 'emotional labour'. Somatology could, therefore, also be viewed as a form of 'emotional labour'. A somatology therapist could describe a treatment as offering stress relief, as well as greater self-confidence to the client. However, a therapist could also describe the struggle to manage their own emotions and behaviour within the private practice (Black \& Sharma 2001b:914).

As observed in the studies mentioned above, the most important principle of somatology is the engagement with clients by talking to them (Linnan et al. 2001:610). Although somatology therapists are aware of the benefits of discussing these aspects with the client, it proves to be an exhausting experience (Black \& Sharma 2001a:110). One's emotional state is closely related to one's efficacy. It demonstrates how imperative self-management is to the therapist. Effective therapy is possible only when a somatology therapist is emotionally stable, physically alert and open to awareness of their own feelings as well as those of the client (Withfield 1980:295).

\section{Problem statement}

During observations and working in private somatology practices, the researcher realised that therapists had demanding careers. It is therefore important for therapists to pursue self-management within their work environment. Therapist distress closely relates to self-management (Wityk 2002:5), since a reduction in self-management could lead to a decline in the well-being of the therapist. The researcher had observed that the therapists became dissatisfied with, or discouraged by, their working conditions in the somatology working environment and could become irritable or anxious during some treatments of clients.

Literature confirms that therapists complain about feelings of tiredness and hopelessness and even not having time for spiritual recreation (Jacobs \& Richter 2002:20). The researcher was unclear about the way in which the therapists in private somatology practices experienced self-management during client therapy, and therefore posed the questions:

- How did therapists experience their self-management during their daily practising of somatological therapy?

- What could be done to improve the self-management of the therapists at private somatology practices?

\section{Purpose of the study}

The purpose of this study was to explore and describe the experiences of therapists from which recommendations for self-management of therapists within private somatology practices were described.

\section{Significance of the work}

Limited research has been undertaken in the field of somatology in South Africa. This article on self-management is the first qualitative research report related to self-management of the somatology therapist.

\section{Research method and design Design}

In this study, a qualitative, descriptive, exploratory and contextual design was used. The aim of qualitative research is to generate knowledge concerned with meaning, discovery and descriptions of self-management (Berg 2004:3). Creswell (2003:1-2) explains the qualitative paradigm as being an inquiry process of understanding a human problem, based on building a picture, formed with words, reporting detailed experiences of the participants, and conducted in a natural setting, as in the case of the therapist in a private somatology practice. A quantitative design would not have served the purpose of this study as each therapist's experiences differed with regard to the phenomenon. 
As an exploratory design, the research began with the phenomenon of interest, namely self-management, and was aimed at investigating the full nature of the phenomenon and the manner in which it is related to the study (Polit \& Hungler 2004:17). The data that were documented in the qualitative study were descriptive, because the researcher was interested in understanding data as described by the participants (Polit \& Hungler 2004:700). The contextual interest of the researcher was aimed at understanding events of therapist selfmanagement within the concrete, natural context of private somatology practices situated in Pretoria-North (Babbie \& Mouton 2001:272). In the context of the study, an average therapist saw 47 clients per week and spent approximately 30-60 minutes per appointment.

\section{Population and sampling}

The accessible population consisted of therapists in private somatology practices in the Pretoria-North region $(n=15)$. Purposive sampling - also known as selective sampling was used, to ensure that specific elements were included in the sample. Information-rich cases were selected from which a great deal could be learnt about the focus of the study (Burns \& Grove 2005:252-253). The inclusionsampling criteria for the study were therapists who had been practising in the private somatology sector for three years or longer and held internationally-recognised or equivalent somatology qualifications (e.g. Itec, SAAHSP or Cidesco). In qualitative data collection no specified number of interviews is stipulated (Plano-Clark \& Creswell 2010:259). Data are saturated when the researcher no longer finds any new information during the interviews and no new themes or categories, or new inputs in new themes or categories, are found (Babbie \& Mouton 2001:288). Data were collected until data saturation occurred, which happened after five interviews, although the researcher continued until 10 interviews had been conducted. A pilot individual interview was conducted with one participant who formed part of the accessible population in the study, to detect any possible flaws in the data-collection method and to refine the datacollection process (Van Teijlingen 2001:290).

\section{Data collection method}

The data collection was conducted by means of conducting individual, unstructured interviews and taking field notes during July 2010. The questioning method allowed the individual free flow of thoughts, feelings and emotions - all of which were charged with meaning. Mulhall (2003:310), as well as Plano-Clark and Creswell (2010:260), argues that it is important to record field notes as soon as possible after events have been observed, in order to add richness to the data. This will enable data triangulation, which is when audio-recorded data from interviews are used to corroborate data from field notes (Tobin \& Begley 2004:393), and field notes are then used to corroborate the interviews.

During the data collection phase, the researcher arrived 10-15 minutes early, in order to introduce herself and prepare the interview setting in a private room. Having volunteered to take part in the study, all participants were given an information sheet which gave them detailed information about the aims of the study, concept definitions and how the interview process would be conducted. A high-quality audio recorder was placed strategically so as to capture the dialogue between the researcher and the participant. One open-ended question was posed: 'How do you experience managing yourself during your daily practice as a somatology therapist in the private sector?' Probing, to provide extensive data, followed the question and the interviews lasted 30-45 minutes.

\section{Data analysis}

The final stage of the study was the analysis of the data by means of open coding (Creswell 2003:190). For this study, the researcher utilised Tesch's steps (quoted in Creswell 2003:192) for the data analysis process:

1. The researcher obtained a sense of the whole picture by reading carefully through the transcribed material. Ideas that came to mind were jotted down.

2. The researcher selected one interview (the first interview of the main study) and went through it asking: 'What is this about?' - not thinking about the information but rather the underlying meaning of the data. The researcher wrote all thoughts in the margin of the given page.

3. When the researcher had completed this task for several interviews, a list was compiled of all the topics. Similar topics were clustered together and placed into columns that were then arranged into 'major topics', 'unique topics' and the 'leftovers'.

4. Subsequently, the researcher took the list and returned to the data. The topics were abbreviated as codes and the codes were written next to the appropriate segments of the text. The researcher tried out this preliminary organising scheme, to see whether new categories and codes emerged.

5. The researcher looked for the most descriptive wording for the topics and turned them into categories. The total list of categories was then further reduced, by once again grouping similar topics. Lines were drawn between categories to show interrelationships.

6. A final decision was made of the abbreviations for each category and the codes were alphabetised.

7. The data belonging to each category were assembled in one place and a preliminary analysis was performed.

The analysis of qualitative data allowed the researcher to discuss, in detail, the various social contours and processes that the therapists used in order to create meaning. The credibility of the coding was checked by an independent coder (De Vos 2005:345).

\section{Ethical considerations}

The rights of self-determination to choose to partake or to withdraw, to privacy of information, to autonomy and confidentiality of names, to fair treatment, to protection from discomfort and harm during the interviews, and the right to grant informed consent were adhered to during the study (Burns \& Grove 2005:181-193). 
Permission was granted by the Higher Degrees Committee (Ref No: AEC42/09) the University of Johannesburg. Further consent was obtained from the private somatology practices and each individual participant gave written informed consent.

\section{Trustworthiness}

Trustworthiness of the study was maintained using Lincoln and Guba's framework (1985) with the following five criteria (Creswell 2007:203): credibility, transferability, dependability, confirmability and authenticity. Credibility was ensured by allowing the participants to express their points of view with regard to the study phenomenon; by means of extended engagement in the field through the individual, unstructured interviews conducted; and by ensuring triangulation through taking field notes. Transferability was ensured by the keeping of thick descriptions of the processes and transactions of the study and through purposeful sampling (Creswell 2007:204). Dependability was ensured through the inquiry audit and descriptions of the research methodology. Confirmability was ensured by using an independent coder and establishing an audit trail (Creswell 2007:204). Authenticity was regarded by Tobin and Begly (2004:132) as being a feature significant to naturalistic inquiry, and this was ensured through appreciating the viewpoint of the participants, enlarging personal constructs and stimulating some form of action with regard to the selfmanagement of the therapist.

\section{Discussion of results}

The research question posed in this study was: 'How do you experience managing yourself during your daily practice as a somatology therapist in the private sector?' After the interviews it became clear that therapists needed to gain a sense of control over cognitive, emotional, spiritual and relational strategies, so as to facilitate their self-management techniques.

\section{Cognitive strategies}

Cognitive processes are defined as the process of being aware, knowing, thinking, learning and judging (Battaglia 2003:7). Cognitive strategies of self-management include internal and external aspects. The data suggested that these strategies formed the biggest part of therapists' self-management. Therefore, it could be assumed that this might be the most significant dimension where therapists would feel the urge to gain a sense of control, and in so doing, improve their selfmanagement abilities.

\section{Internal cognitive strategies}

These internal aspects referred to the gaining of control within oneself, which included self-talk, self-reflection, selfknowledge, focused attention, the ability to let go, thinking ahead, planning and goal setting.

\section{Self-talk}

Dialogue with the self (self-talk) could facilitate, gaining an internal sense of control. One participant believed that one could not achieve successful self-management without any self-motivation:

'... self-motivating, you have got to do self-motivating all day long. So that's the only way to do it. But you need to be a selfmotivator, because if you are not, you are not going to make it [self- management] right.'

Dialogue with the self also calmed a therapist:

'Uhm ... I just tell myself to calm down ... and that's basically all I do. Just calming myself down taking a breath and ... then I do the treatment.'

The findings were indicative of self-monitoring being part of such an internal dialogue. Self-monitoring describes both individuals who monitor their own time and environment actively, as well as an awareness of issues or situations that may prevent individuals from being self-managed (Gerhardt 2007:11).

\section{Self-reflection}

The importance of self-reflection in the form of analysing choices was indicated by:

'... if you go and think, then you realise but ok, here I had two choices, did I do the right thing? Or did I decide on the right one? So I think it is important to think about the matter ...'

Self-reflection is needed in order to obtain knowledge about yourself. Hence, a participant stated:

'... the most important person to get to know is yourself.'

\section{Self-knowledge}

Baldacchino and Draper (2001:853) confirm that self-knowledge is important in order to gain a sense of control over cognitive strategies. Knowing who you are internally is your prime assistance in the workplace. One should understand one's natural response to self-awareness, since it is related to selfcaring and to knowing when your body needs recharging and rest. In other words, self-knowledge relates to selfmanagement, by knowing what you need to regain that sense of control.

\section{Focused attention}

Focused attention was perceived as a characteristic that allows the therapist to do various things, one of which is the ability to exercise self-management:

'... ja, if you have a good concentration ... if you can concentrate, you can do a lot of things.'

Concentrating could make the therapist more aware of the client, as well as internal or external environmental issues which could facilitate self-management. When considering the content of therapy, whilst providing treatment to a client, focusing on the client and the expected outcomes are essential (Langhoff et al. 2008:76).

\section{Letting go}

Just letting go seemed to relate to parting with the things that impacted negatively on the therapist:

'You let it go. I say this is because you will have 10 million people that say that [something bad] and then you will have 10 million people that come to you and say we like you a lot.' 
The findings indicated that letting go was a process involving cognitive strategies. It is a conscious choice. The literature states that the capacity to let go of negative thinking increases the individual's capacity for cognitive flexibility (Frewen et al. 2008:764).

\section{Thinking ahead}

Thinking ahead allowed one participant to deal with a situation before the situation presented itself, for instance treating a client whilst dealing with another client who was waiting in the reception area:

'So you really have to think ahead, ok, while this client is waiting, make her some coffee, ask her to relax, you know, let my assistant massage her hand or just her head.'

\section{Planning and goal setting}

Participants mentioned the importance of planning and goal setting. Planning could prepare therapists for unforeseen circumstances, giving them a sense of control over their present situation:

'To do your planning ... you have to think ahead and you have to be ready for any challenge.'

On the other hand, goal setting could give the therapists a sense of control over where they would like to be in future. The following excerpt provides an example of goal-setting strategies displayed by a participant:

'... you need to write down how many clients you've done in a month and how many you still need, you need to have a goal, you need to work out targets for yourself ...'

Goal setting is a step toward becoming a self-managed therapist (Gerhardt 2007:11).

\section{External cognitive strategies}

The external aspects of the cognitive strategies to self-manage included aspects that the therapist wanted in order to gain a sense of control over that which was not part of the self, but the external environment. These aspects included their communication skills (talking), the ability to custom fit a treatment, the flexibility in their time, setting boundaries, demarcating work and family life, and physical touch.

\section{Talking}

Applying and gaining a sense of control over communication skills (talking) could be seen as a cognitive strategy. A therapist indicated that conversations with clients included everyday issues, where the therapist might pay attention to what a client said, without getting emotionally involved:

'Small talk [laugh]. Definitely... put the radio on, that's the best manner, ... you can always make a comment about it.'

Small talk could serve to establish social relationships and strengthen the therapeutic relationship with the client (Mullany 2006:61).

\section{Custom fitting the treatment}

In order to be able to custom fit the treatment, one has to know why the client is visiting the practice. A participant stated:
'... just keep contact with what the client really needs ... Just listen ... most people just need a bit of attention ... and if you can see what she is here for ... then you just zoom in and kill her [laugh].'

Somatology therapists are expected to give a client a moraleboosting treatment delivered within the context of attentiveness to the client's individual needs and circumstances, as confirmed by Toerien and Kitzinger (2007:647).

\section{Time management}

Self-management was experienced as the ability to manage one's time, whilst still providing value for money:

'Time management and value for money.'

It would be useful if the therapist had the option to 'cut their time', as one participant stated:

'Then I would say, they were late, it is probably bad, but you cut some of their time, to help the other client that was on time.'

\section{Setting personal boundaries}

Furthermore, cognitive strategies determine setting personal boundaries. One therapist indicated that it worked to build a barrier and not to take any offensive remarks personally:

'What works is to sort of build a barrier, not to get too emotionally attached to clients ... when a client says something to you that can be offensive, just take it ... in another way, but in such way that it won't hurt you.'

Boundaries serve as strategies to deal with work-related stressors and improve self-management strategies (Ekendahl \& Wengstrom 2008:43).

\section{Demarcation of work and family life}

Boundaries also extend to include the demarcation of work and family life. A therapist expressed how failing to create work and family life boundaries could cause one's own downfall, because the client will sense such imbalance:

'... make sure that you sort your personal life out and you leave that at home.'

\section{Physical touch}

The only reference to physical strategies was made by one participant referring to physical touch. The therapist discussed a sense of belonging and purpose in their work environment:

'... to be a therapist, it has to be your heart and soul, and body and everything. This is who you are and what you can give to people ... because it is a 'give and take'. So I think absolutely, it has to be your love language, to touch. If touch is in your love language, clients will know it.'

Cognitive strategies allow one to gain a sense of control. Once the therapist is in a space where self-management is practised, strategies can be improved.

\section{Emotional strategies}

The emotions of the therapist could play a pivotal role in their self-management strategies to achieve control. Such emotional strategies included faking it as opposed to being authentic, the emotional awareness of the therapist, the ability to manage emotions, empathy and reserving one's judgment. 


\section{Faking it}

Therapists stated they often had to fake being composed, whilst in reality they were actually either angry or sad:

'Mmm. Faking it ... you fake it when you're angry. I think that's when I fake it.'

Another participant stated:

'I really need her [the client] to trust me ... it's probably gonna happen again ... I am normally late, so please expect to wait ... I must be honest to say that you are probably going to wait again.'

Van de Mortal (2006:40) mentioned that faking it related to the tendency of people to present a favourable image of themselves (such as being calm and neutral), allowing individuals to portray a positive image of themselves.

\section{Emotional awareness}

Emotional awareness is important and therapists cannot let their emotions get in the way of performing their professional duties.

'I cannot ... uhm, let my ... uh, emotions in the way ...'

Another participant indicated that she consciously decided to fake her emotions, as a means of managing emotions:

'Like with your difficult clients, the nasty ones, that tell you how to do your job. There you have to control yourself. You should still smile and carry on.'

The therapist within a somatology practice should develop a calm, confident and competent attitude. According to Halpern (2007:696), a therapist has to recognise their own emotions, attend to negative emotions over time and attune her- or himself to the client's verbal and non-verbal emotions in order to be efficient at self-management.

\section{Empathy}

A participant indicated that the client appreciated the empathy shown by the therapist, but that it was necessary to keep issues confidential between the client and the therapist:

'It is nice when someone else cries with them [the client]; it is also important that they know it should be confidential.'

Vanaerschot and Liestaer (2007:339) argue that empathy is a primary relationship factor and that empathy is an important way in which the therapist can communicate acceptance, warmth and real commitment to a client. A lack of empathy increases client dissatisfaction (Halpern 2007:696).

\section{Reserving judgement}

It is sometimes difficult to reserve judgement towards clients. A participant indicated that one could reserve one's judgment and that faking it could be the answer:

'I say to myself, just breath. Doesn't help you to lose it. Uhm. The client's always right. It's the type of brain washing yourself.'

If therapists judge their clients, they might cause the relationship between themselves and the clients to break down. The more cognitively-orientated therapists are, the more they tend to think about how best to assist a client and are less likely to reflect on feelings of judgement toward a client (Schroder, Wiseman \& Orlinsky 2009:52). Emotional strategies are needed to gain control, and some of the strategies can be difficult for the therapist to master.

\section{Spiritual strategies}

Spirituality is derived from the Latin word spiritus. Spirit, the essential part of the person, 'controls the mind and the mind controls the body' (Baldacchino \& Draper 2001:834). The findings indicated that prayer and displaying a positive focus were needed. One participant shared that she prayed every day before starting her working day, to stay focused, and also when something went wrong:

'... we pray about it, it keeps you focused ... it makes you strong ... God makes you strong ... He will help you.'

\section{Positive focus}

An aspect of spiritual strategies practised by therapists was displaying a positive focus and attitude. A participant stated that the best form of self-management is to be positive:

'... it's just to be positive, and it's difficult, because some days you're just not, in the mood. That's the best self-management you can do, is to be positive.'

A study conducted by Ekendahl and Wengstrom (2008:45) found that faith could have a sheltering function and could facilitate a coping mechanism (or self-management) for individuals working with clients on a daily basis, since they had a focus in time of need.

\section{Relational strategies}

Relational strategies refer to social strategies that the therapist uses to gain a sense of control and self-management on a daily basis. The discussion on relational strategies includes networks of relationships that provide personal support and working as a team in the somatology practice.

\section{Network of relationships}

The network of relationships that existed in providing personal support included relationships with personal friends, as well as work colleagues. A participant explained why it was different to build a relationship with a colleague as opposed to building a relationship with a friend:

'It [talking to colleagues] might not be easy because you can't trust everybody, that's the difficult part. You don't know a colleague versus a friend ... If it's a friend you can say anything and everything, and feel safe about it, but with a colleague you don't know what might happen, ... and you find that whatever you've said might backfire ... a colleague might just say something that you've shared in confidence, that may put you at a very detrimental stance.'

\section{Working as a team}

In the study conducted by Ekendahl and Wengstrom (2008:43), they found that having a positive relationship with colleagues, participating in social activities together with colleagues, sharing problems with others, working as a team and sharing private time with family and friends, were factors that were necessary for employees working with clients. 


\section{Friendship}

A participant expressed the importance of having a friend outside of the industry that understood what a therapist went through, especially when the person was giving advice:

'I have an understanding aunt ... she's a radiologist. And I can always go and talk to her. And I can open up and say 'listen, I've had a crap day, this is what happened', and I feel as a therapist that you need to unload.'

In a conference paper (Anonymous 2008:2), the author indicated that social support (such as support from family and friends) played an important role in well-being throughout a person's life.

\section{Recommendations}

The awakening to the mastery of self-management is as unique as the individual therapist and/or the private somatology practice. Because the researcher was unclear as to how selfmanagement can be improved, a second question was posed, namely, 'What could be done to improve the self-management of the therapists at the private somatology practices?' Based on the experiences of participants in the study, four recommendations were made about the self-management of the somatology therapist in the work environment.

\section{The therapists should utilise cognitive strategies to gain a sense of control over self-management}

Regarding the internal environment aspects, the therapist should plan to enable conscious decision making to strive to be the best version of her- or himself during the contact time with clients. Self-coaching facilitates this, by enabling the therapist to choose to be their best for a specific period of time. Practising self-appreciation, on a daily basis, benefits the self-management capability of the therapist by directing the therapist in finding happiness within her- or himself. The therapist should practise self-praise for the work completed and ensure that she or he plans incentives for such an event. The therapist should utilise a dialogue periodically with the self, especially in the form of self-affirmative talk. Only positive self-dialogues should be used and the therapist should listen to the language used (when speaking of the self and referring to oneself) (Covey 1994:93). Therapists will have to 'fake it' by controlling their emotions when faced with a negative emotion of any sort. This can be achieved by remaining neutral, not showing true emotions and 'getting into [the] character' of being a therapist whose first priority is the well-being of the client. Empathy should be shown toward the client by means of a genuine, confirming and validating encounter of becoming aware of the client's uniqueness, by suppressing the self and by grasping the client's experiences (Vanaerschot \& Lietaer 2006:338). The therapist should show compassion toward the clients, must control or set aside their own interests, values and judgment and 'feel with' the client (Van Der Cingel 2009:134) in order to show true compassion.

In order to foster a positive therapeutic relationship, the therapist should suspend judgement or control her or his feelings of the client. This is done by showing high levels of unconditional positive acceptance toward the clients
(Langhoff et al. 2008:69) and ranking the interest of the client first (Van Der Cingel 2009:132).

When considering the external environment, it is vital that each therapist set clear targets and goals for the near future (e.g. target for today) and far future (e.g. 5-year strategic plan) for themselves [target setting]. Taking time to write such targets down ensures that the therapist adheres to them. It is important for each therapist to possess the relevant knowledge regarding the therapies they perform. In line with being focused, the therapist should plan and think ahead. Goal setting goes hand-in-hand with planning. Goals must be specific and challenging, but attainable, and accepted by the individual, to ensure commitment and persistence in order to be effective (Moore et al. 2001:261). It is also critical that short-term goals link to long-term goals (Covey 1994:163). The therapist should be competent in all the treatments and treatment options and should custom fit each treatment to suit the needs of each client, through organising and planning, as each client is different and presents different needs (Orem, Binkert \& Clancy 2007:101).

The therapist has to create boundaries with colleagues and family. Boundaries will include, (1) personal boundaries, which include not getting too involved with fellow therapists or clients; and (2) creating boundaries between family and work life, thus not letting the one affect the other. The therapist has to be time-competent [time management], planning not to waste time and to complete their treatments quickly yet effectively. Time management relieves pressure, and may mean cutting the clients' time, when they are late, to avoid the therapist being late for the next treatment. Attending a course on time management would be beneficial.

\section{The therapists should utilise emotional strategies to gain a sense of control over self-management}

The therapist should believe that they are making a difference when treating the client. Planning one's thoughts regarding one's value to the client can facilitate a positive attitude in the therapist, providing a sense of belonging and satisfaction. When providing a treatment (such as a massage) the therapist must balance their mind, by practising controlled slow and deep breathing (a relaxation breathing exercise). Slow, deep and rhythmic breathing makes the heart rate slower, improves muscular relaxation and brings about a feeling of calm (Gould 2003:208). This aids in healing the therapist by relieving pressure and the feeling of burnout. A positive relationship with the self allows the therapist not give too much of him- or herself. Creating and directing boundaries in a positive manner when dealing with clients is essential. Self-knowledge allows the therapist to know when to stop giving and even prevents burnout. Detachment after each treatment (Halpern 2007:696) is vital.

\section{The therapists should utilise spiritual strategies to gain a sense of control}

Therapists should have a positive sense of belief in themselves, as this influences how other people see them. This can be 
achieved by reflecting on instances when therapists are at their best (Orem et al. 2007:46). Therapists should be passionate about their work. By organising and directing monthly self-management reflective sessions with other therapists, in which each therapist reflects on their self-management progress during that month as well as the positive aspects of their work, their passion for the job at hand will be both ignited and maintained. Self-meditation should be practised as an art or technique of silencing (directing) the mind, allowing one to tune into one's inner-self to centre oneself (Van Der Merwe 2004:199). This enables the therapist to gain control over the self and their state of mind and allows the therapist to know her- or himself. The therapist should find a quiet space for 10 minutes before commencement of the working day to focus on their breathing. This allows for spiritual renewal (Covey 1994:294).

\section{The therapists should utilise social strategies to facilitate self-management}

Self-management must encompass other family responsibilities. The therapist must organise their life by separating work, family life, problems and responsibilities. Self-management improves this demarcation. The self-managed therapist must foster a healthy therapist-client relationship. The client and therapist should share knowledge of one another so as to facilitate the bonding process (Orem et al. 2007:93). Self-management allows the therapist to cultivate a healthy relationship with fellow colleagues, enabling teamwork. Boundaries must be established and maintained, by directing and controlling relationships with team members and clients.

\section{Limitations of this study}

Therapists that participated in this study did so amidst contact sessions with their clients, bringing about a time limit on the duration of the interviews, which could have limited the amount of information shared by the therapist. Even though data saturation occurred after five individual interviews, 10 interview sessions were completed for the data in this study.

The therapists did not complete or read through the documentation supplied to them prior to the interview. The aim of these documents was to define self-management in the context of this study and for them to reflect on their best experiences of self-management. The documentation was, however, discussed with the participants before initiation of the study.

The study was conducted in private somatology practices, situated only in Pretoria-North, therefore generalisation outside of this environment may be difficult to justify.

\section{Recommendations for future research}

Research in the field of somatology and self-management in the context of somatology is at this stage still very limited. Supplementary research needs to be conducted in this wide field of study, a field of which we, in South Africa, carry very limited knowledge. The following topical issues could be considered for future research:

- The influence of the therapist self-management and treatment outcomes.

- The effect(s) of self-management on the success of privately-owned somatology clinics.

- The nature of somatology as a business.

- The critical aspects of the therapist-client relationship.

- Self-management and the support of family and friends.

- Self-management and team work.

- The effect on the therapist's well-being when managing difficult clients.

- The impact of prioritising clients' needs ahead of the therapists' own by applying self-management.

- The effect on the therapist of 'faking it'.

- The effect of team work on the ability to self-manage.

\section{Conclusion}

This qualitative study described that there is an acute necessity for self-management during (especially) client interaction and other aspects of a working day in the life of a therapist. In order to master self-management, the therapist must master both their internal and external environment. The internal environment would consist of their relationship with the self (physical, emotional and spiritual) and with others (clients, family, colleagues, managers and the industry itself). The external environment can refer to the world of work (setting targets, goals, etc.). This study explored and described the experiences of therapists and made recommendations for self-management within the private somatology practice. In so doing, the study identified that there is a definite need to nurture the therapist within this demanding working environment which we call the somatology practice.

\section{Acknowledgments Competing interests}

The authors declare that they have no financial or personal relationship(s) which may have inappropriately influenced them in writing this paper.

\section{Author's contributions}

Prof K.J. (University of the Western Cape) was the supervisor that wrote the manuscript, based on the results of the master studies of K.R. (now K. Henrico) (Masters student, University of Johannesburg).

\section{References}

Anonymous, 2008, Effects of Friendship, Conference paper, 2008, International Communication Association 12, 1-21.

Babbie, E. \& Mouton, J., 2001, The practice of social research, Oxford University Press, Cape Town.

Battaglia, S., 2003, The complete guide to aromatherapy, 2nd edn., The International Centre of Holistic Therapy, Brisbane. http://dx.doi.org/10.1046/j.1365-2648.2001. 01814.x, PMid:11422554

Baldacchino, D. \& Draper, P., 2001, 'Spiritual coping strategies: a review of the nursing research literature', Journal of Advanced Nursing 34(6), 833-841.

Berg, B.L., 2004, Qualitative research methods for the social science, 5th edn., Pearson \& Allyn and Bacon, Boston. 
Black, P. \& Sharma, U., 2001a, 'Men are real, women are "made up": beauty therapy and the constructions of femininity', Sociology Review 49(1), 100-116.

Black, P. \& Sharma, U., 2001b, 'Look good, feel better: beauty therapy as emotional labour', Cambridge Journal 35(4), 913-931. http://dx.doi.org/10.1111/1467-954X.00246

Burns, N. \& Grove, S.K., 2005, The practice of nursing research: conduct, critique and utilisation, 5th edn., Elsevier, Philadelphia.

Covey, S.R., 1994, The seven habits of highly effective people, Simon \& Schuster, London.

Creswell, W.F., 2003, Research design: qualitative and quantitative approaches, 2nd edn., Sage, New Dehli.

Creswell, W.F., 2007, Qualitative inquiry \& research design: choosing among five approaches, 2nd edn., Sage, New York.

De Vos, A.S., 2005, Research at Grassroots, Van Schaik, Pretoria.

Ekendahl, M. \& Wengstrom, Y., 2008, 'Coping process in a multidisciplinary health care team-a comparison of nurses in cancer care and hospital chaplains', European Journal of Cancer Care 17(1), 42-48. http://dx.doi.org/10.1111/j.1365-2354.2007.00801.x PMid:18181890

Frewen, P.A., Evense, E.M., Maraj, N., Dozois, D.J.A. \& Patridge, K., 2008, 'Letting go: mindfulness and negative automatic thinking', Cognitive therapy and research 32 758-774. http://dx.doi.org/10.1007/s10608-007-9142-1

Gerhardt, M., 2007, Teaching self-management: the design and implementation of selfmanagement tutorials, Journal of Education for Business 83(1), Sept/Oct, 11-17. $\mathrm{http}: / / \mathrm{dx}$.doi.org/10.3200/JOEB.83.1.11-18

Godfrey, S., 2003, The principles and practice of electrical epilation, 3rd edn., ButterworthHeinemann, Burlington.

Gould, F., 2003, Arometherapy for holistic therapists, Nelson Thornes, London.

Halpern J., 2007, 'Empathy and patient-physician conflicts', Journal of General Interna Medicine 22(5), May, 696-700. http://dx.doi.org/10.1007/s11606-006-0102-3, PMid:17443382, PMCid:1852904

Jacobs, M. \& Richter, K., 2002, The reality of working as a somatologist - not as glamorous as it seems, Tshwane University of Technology, Pretoria.

Jooste, K., 2010, Leadership in health services management, 2nd edn., Juta, Kenwyn.

Kreitner, R. \& Kinicki, A., 1998, Organizational behavior, 4th edn., Irwin McGraw-Hill, Boston.

Langhoff, C., Baer, T., Zubragel, D. \& Linden, M., 2008, 'Therapist-patient alliance, patienttherapist alliance, mutual therapeutic alliance, therapist-patient concordance, and outcome of CBT in GAD', Journal of Cognitive Psychotherapy: An International Quarterly 22(1), 68-79. http://dx.doi.org/10.1891/0889.8391.22.1.68

Lincoln, Y.S., \& Guba, E.G., 1985, Naturalistic inquiry, Sage Publications, Beverly Hills, California.

Linnan, L.A., Kim, A.E., Wasilewski, Y., Lee, A.M., Yang, J. \& Solomon, F., 2001, 'Working with licensed cosmetologists to promote health: results from the North Carolina beauty and health pilot study', Preventative Medicine 33(6), 606-612. http:// dx.doi.org/10.1006/pmed.2001.0933, PMid:11716657

Merriam-Webster.com, 2012a, Definition of experiences, viewed 16 March 2013, from http://www.merriam-webster.com/dictionary/experiences
Merriam-Webster.com, 2012b, Definition of therapist, viewed 16 March 2013, from http://www.merriam-webster.com/dictionary/therapist

Moore, D.W., Prebble, S., Robertson, J., Waetford, R. \& Anderson, A., 2001, Selfrecording with goal setting: a self-management programme for the classroom, Educational Psychology 21(3), 255-265.

Mulhall, A., 2003, 'In the field: notes on observation in qualitative research', [online] Journal of Advanced Nursing 41(3), 306-313, viewed 22 April 2010, from http:// www.ncbi.nlm.nih.gov/pubmed/12581118

Mullany, L., 2006, “'Girls on tour”: politeness, small talk, and gender in managerial business meetings', Journal for Politeness Research 2(1), 55-77.

Orem, S.L., Binkert, J. \& Clancy, A.L., 2007, Appreciative coaching: a positive process for change, Jossey-Bass, San Francisco.

Plano-Clark, V.L. \& Creswell, J.W. 2010, Understanding research, a consumer's guide, Merril, New Jersey.

Polit, D.F. \& Hungler, B.P., 2004, Nursing research: principles and methods, 7th edn. Lippincott, Williams \& Wilkins, Philadelphia.

Schroder, T., Wiseman, H. \& Orlinsky, D., 2009, "“You were always on my mind": therapists' intercessions experiences in relation to their therapeutic practice,
professional characteristics, and quality of life', Psychotherapy Research 19(1), 42-53. http://dx.doi.org/10.1080/10503300802326053, PMid:18815946

Tobin, G.A. \& Begly, C.M., 2004, 'Methodological rigour within a qualitative framework', Journal of Advanced Nursing 48(4), 313-396. http://dx.doi.org/10.1111/j.13652648.2004.03207.x, PMid:15500533

Toerien, M. \& Kitzinger, C., 2007, 'Emotional labour in the beauty salon: turn design of task-direct talk', Feminism and Psychology' 17(2), 162-172. http://dx.doi.org/ 10.1177/0959353507076548

Van de Mortal, T.F., 2006, 'Faking it: Social desirability response bias in self reporting research', Australian Journal of Advanced Nursing 25(4), 40-47.

Van Der Cingel, M., 2009, 'Compassion and professional care: exploring the domain', Nursing Philosophy 10(2), 124-136. http://dx.doi.org/10.1111/j.1466-769X.2009. 00397.x, PMid:19291200

Van der Merwe, A., 2004, Stress solutions: understand and manage your stress for a balanced, energized life, Tafelberg Publishers, Cape Town.

Van Teijlingen, E., 2001, 'The importance of conducting and reporting pilot studies', Journal of Advanced Nursing 34(3), 289-295. http://dx.doi.org/10.1046/j.13652648.2001.01757.x, PMid:11328433

Vanaerschot, G. \& Liestaer, G., 2007, 'Therapeutic ingredients in helping session episodes with observer-rated low and high emphatic attunement: a content analysis of client and therapist postsession perception in three cases', Psychotherapy Research 17(3) 329-342. http://dx.doi.org/10.1080/10503300600650910

Withfield, M.D., 1980, 'Emotional stresses on the psychotherapist', Canadian Journal of Psychiatry 25(4), 292-296.

Wityk, T.L., 2002, 'Burnout and the ethics of self-care for therapists', viewed 16 March 2013, from http://www.google.co.za/url?sa=t\&rct=i\&q=\&esrc=s\&source=web\&cd

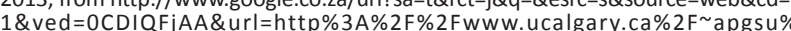
2FNetwork 2 Fresearch\%2FETHICSP2 2FNetwork s346uaV84tbLLw\&bvm=bv.43828540,d.d2k 